\title{
Arsenic and Manganese Contamination of Drinking Water Resources in Cambodia: Coincidence of Risk Areas with Low Relief Topography
}

\author{
Johanna Buschmann ${ }^{1}$, Caroline Stengel ${ }^{1}$, and Mickey L. Sampson ${ }^{2}$, Michael \\ Berg*1 \\ Revised Manuscript es062056k for \\ ENVIRONMENTAL SCIENCE AND TECHNOLOGY
}

${ }^{1}$ Swiss Federal Institute of Aquatic Science and Technology, Eawag, CH-8600 Dübendorf, Switzerland

${ }^{2}$ Resource Development International - Cambodia, RDIC, P.O. Box 494, Phnom Penh, Cambodia

* Corresponding author. Phone: +41-44-823 50 78; Fax: +41-44-823 5028 E-mail: michael.berg@eawag.ch

Keywords

Arsenic contamination, groundwater, drinking water, low relief topography, seasonal fluctuation, health threat, reductive dissolution, anoxic conditions, manganese, iron, ammonium, total hardness, Phnom Penh, Upper Mekong Delta, Kandal, Prey Vêng, Takeo Province

This document is the Accepted Manuscript version of a Published Work that appeared in final form in Environmental Science and Technology, copyright (C) American Chemical Society after peer review and technical editing by the publisher. To access the final edited and published work see http://doi.org/10.1021/es062056k. 


\begin{abstract}
Arsenic contamination of groundwater has been identified in Cambodia, where some 100,000 family-based wells are used for drinking water needs. We conducted a comprehensive groundwater survey in the Mekong River floodplain, comprising an area of $3700 \mathrm{~km}^{2}(131$ samples, 28 parameters). Seasonal fluctuations were also studied. Arsenic ranged from 1$1340 \mu \mathrm{g} \mathrm{L}^{-1}$ (average $163 \mu \mathrm{g} \mathrm{L}^{-1}$ ), with 48\% exceeding $10 \mu \mathrm{g} \mathrm{L}^{-1}$. Elevated manganese levels $\left(57 \%>0.4 \mathrm{mg} \mathrm{L}^{-1}\right)$ are posing an additional health threat to the 1.2 million people living in this area. With 350 people $\mathrm{km}^{-2}$ potentially exposed to chronic arsenic poisoning, the magnitude is similar to Bangladesh $\left(200 \mathrm{~km}^{-2}\right)$. Elevated arsenic levels are sharply restricted to the Bassac and Mekong River banks and the alluvium braided by these rivers (Kandal Province). Arsenic in this province averaged at $233 \mu \mathrm{g} \mathrm{L}^{-1}$ (median $100 \mu \mathrm{g} \mathrm{L}^{-1}$ ), while concentrations to the west and east of the rivers were $<10 \mu \mathrm{g} \mathrm{L}^{-1}$. Arsenic release from Holocene sediments between the rivers is caused by reductive dissolution of metal oxides. Regions exhibiting low and elevated arsenic levels are coincident with the present low relief topography featuring gently increasing elevation to the west and east of a shallow valley understood as a relict of pre-Holocene topography.
\end{abstract}




\section{Introduction}

Arsenic is a persistent contaminant in groundwater and drinking water in countries such as Bangladesh, Vietnam, Argentina and the United States (1-3). The Bengal Delta is the most prominent region because some 43 million people have been drinking arsenic-rich water for 20-30 years (1). Health problems are reported to occur after 10-15 years of chronic exposure to elevated As levels around $50 \mu \mathrm{g} \mathrm{L}^{-1}$. The World Health Organization (WHO) recommends $10 \mu \mathrm{g} \mathrm{L}^{-1}$ As as drinking water guideline.

Drinking water supplies in Cambodia are dependent on groundwater resources. Although surface water is still used as drinking water in some areas, family-based groundwater tubewells were becoming popular during the last 10 years. In Kandal Province, some 1 million people have stopped using surface water due to bacterial diseases that are at least partly responsible for a high infant mortality (71 deaths/ 1000 live births) (4).

Arsenic concentrations of $100-500 \mu \mathrm{g} \mathrm{L}^{-1}$ were for the first time identified in Cambodia in 2000 through a small scale drinking water quality screening in hand-pumped tube-wells (5). Consequently, several NGOs have tested groundwater by field-test kits and identified areas where $20 \%$ of the tube-wells had As levels $>50 \mu \mathrm{g} \mathrm{L}^{-1}$ and $50 \%$ were $>10 \mu \mathrm{g} \mathrm{L}-1$. However, only four publications dealing with the arsenic problem in groundwater of the Mekong Delta (including Vietnamese part) are published to date (6-9). They provide a very coarse picture of the situation, and prediction according to their presented risk maps is misleading in certain areas. For example, high risk areas are suggested for the whole Kandal Province and neighboring Takeo and Prey Vêng Provinces $(6,7)$, whereas we could show that there are sharply confined low arsenic regions west and east of the rivers Bassac and Mekong. Moreover, in contrast to Stanger et al. (7), this study demonstrates that groundwater arsenic is not an ephemeral problem.

The Mekong Delta is located in southern Vietnam and neighboring Cambodia between $8^{\circ} 30^{\prime}$ to $11^{\circ} 30^{\prime} \mathrm{N}$ and $104^{\circ} 40^{\prime}$ to $106^{\circ} 50^{\prime} \mathrm{E}$ and is confined by the South China Sea in the southeast, the Gulf of Thailand in the west, the Vamcodong River in the northeast and a well-defined late Pleistocene terrace to the north. The Mekong River is $4300 \mathrm{~km}$ long and has a catchment area of 520,000 $\mathrm{km}^{2}$. It originates in the Tibetan Plateau, and flows through China, Myanmar, Laos, Thailand, Cambodia and Vietnam. Close to Phnom Penh, the Mekong divides into two branches, the Mekong to the southeast and the Bassac River to the south. To the north, the Tonle Sap River is connecting the Tonle Sap Lake with the Mekong River. The depositional environment in Phnom Penh is largely limited to a linear trending valley that is fault 
controlled along the Bassac and limited by Pleistocene uplands adjacent to the Mekong. The Mekong River in Cambodia is a broad river that becomes tidal upstream to the northeast of Phnom Penh, near Kampong Cham (6). The delta plain has an area of about $62,000 \mathrm{~km}^{2}$, with $10,000 \mathrm{~km}^{2}$ belonging to Cambodia and the rest located in southern Vietnam.

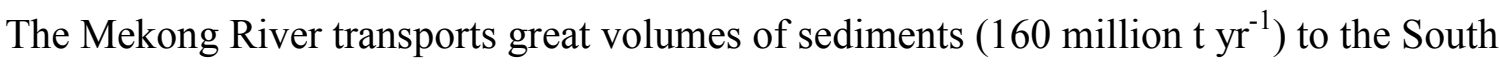
China Sea and contributes up to $30 \%$ of the world's ionic input to the ocean $(10,11)$. The delta consists almost entirely of young alluvial soils (12). Sediment composition and groundwater characteristics vary in a complicated way and are known only in limited areas of the Vietnamese part of the Mekong Delta (13). The climate is humid and tropical, with average temperatures of $27-30^{\circ} \mathrm{C}$. The rainy season lasts from April to November (14). For the study presented here, we collected 131 groundwater samples from private tube-wells in the Cambodian Mekong River floodplain (Kandal, Takeo and Prey Vêng Provinces) for the determination of 28 hydrogeochemical parameters. To our knowledge, this is the first comprehensive published database of regional as well as temporal groundwater composition. The goals were (i) to study the magnitude and distribution of arsenic and manganese contamination (ii) to identify hydrogeological features of the risk areas (iii) to elucidate mechanism(s) of arsenic release, and (iv) to study the temporal trends of groundwater contamination. The main triggers leading to arsenic as well as manganese release are discussed with respect to risk assessment.

\section{Methods}

Study Area and Temporal Fluctuations. In November and December 2004 and March 2006 , family-based tube-wells were selected over an area of $3700 \mathrm{~km}^{2}$ with a density of $\approx 1$ sample per $30 \mathrm{~km}^{2}$. A total of 131 groundwater samples were collected of which 25 are originating from the west of Bassac River in Kandal and Takeo Provinces (group "west"), 90 between the Bassac and Mekong River in Kandal Province (group "middle") and 16 east of Mekong River in Prey Vêng Province (group "east”) (see Figure 1). Seven wells located west of and very close to Bassac River (north of $11^{\circ} 47^{\prime} \mathrm{N}$ ) were attributed to the "middle" group due to the meandering structures observed which were otherwise only found between the rivers. Moreover, four river water samples (Tonle Sap River, Bassac, Mekong south and north of Phnom Penh) were analyzed. In order to study fluctuations in groundwater composition, another 26 wells located in a special study area of the "middle region" (Kandal 
Province) were sampled in April 2004, August 2004 and January 2005 (for sampling design, see Figure SI 1).

Sample Collection. Groundwater was collected at the tube by a hand- or electrical pump. Samples were taken after 10 minutes of pumping, i.e., after the oxygen concentration in the water reached a stable value. Redox potential against SHE, $\mathrm{pH}$, temperature, oxygen and conductivity were recorded on-site by a portable system YSI 556 and a WTW Multi 340i (John Morris Scientific Pty Ltd). The samples were filled in polypropylene bottles (rinsed with $1 \% \mathrm{HNO}_{3}$ and 3 times with distilled water before shipping and 3 times with well-water before taking the sample). An aliquot $(60 \mathrm{~mL})$ for the analysis of metals, ammonium and phosphate was $0.45 \mu \mathrm{m}$ filtered (cellulose nitrate filter, Schleicher\&Schuell, Germany) and acidified with approximately one milliliter of concentrated nitric acid (65\%, Fluka, Switzerland) to reach a $\mathrm{pH}<2$. Anions, alkalinity and DOC were determined in non-acidified and non-filtered water $(120 \mathrm{~mL})$. The samples were shipped to Switzerland by express mail and stored at $4{ }^{\circ} \mathrm{C}$ in the dark until analysis. Control samples transported to Cambodia and back did not show any impact of transport on the analytical results.

Chemical Analysis. The chemical constituents in the groundwater samples were quantified in triplicates. The full georeferenced database of measured concentrations is available as supporting information (Table SI 1). Arsenic concentrations were measured in parallel by atomic fluorescence spectroscopy (AFS, Millennium Excalibur, PS Analytical, UK) and inductively-coupled-plasma mass spectrometry (ICP-MS, Element 2, Thermo Electron, Bremen, Germany). Cross-evaluation of these methods agreed within 5\% (Figure SI 2). Fe, $\mathrm{Mn}, \mathrm{Na}, \mathrm{K}, \mathrm{Ca}, \mathrm{Mg}$, and $\mathrm{Ba}$ concentrations were measured by inductively-coupled-plasma optical emission spectroscopy (ICP-OES, Spectro Ciros CCD, Kleve, Germany); Co, Ni, Cu, $\mathrm{Zn}, \mathrm{Pb}, \mathrm{Cr}, \mathrm{Cd}$ and $\mathrm{Ba}$ by ICP-MS; ammonium and phosphate by photometry; nitrate, sulphate and chloride by ion chromatography (Dionex, Switzerland); alkalinity by titration; and dissolved organic carbon (DOC) with a TOC 5000 A analyzer (Shimadzu, Switzerland). Details on quality assurance are given in the SI.

Statistical Analysis. For the three regions "west", "middle" and "east", statistical analysis of variance (ANOVA) was conducted using Systat 11 (Table SI 2). Log-transformations were performed for all parameters that did not have a normal distribution of residuals (residual analysis using the Tukey-Anscombe plot and the Q.-Q. plot). Parameters including zerovalues were log-transformed after performing a correction after Stahel (15). Pairwise comparison probabilities (p) were calculated for each pair of regions using the Bonferroni adjustment. 
The fluctuations over time (three times: April 2004, August 2004 and January 2005) were also variance analyzed in a mixed model. Here, two factors were used: time (fixed factor) and well-number (random factor). The interaction term was omitted using the General Linear Model (GLM). Probabilities are given in Table SI 3 and average concentrations with standard errors for selected parameters are given in Figure SI 3 a,b.

In order to identify parameter associations for the three regions studied, principal component analysis (PCA) was performed. A detailed description and the results are given in the SI (Figure SI 4).

\section{Results and Discussion}

Arsenic contamination and redox parameters. Figure 1 shows the arsenic distribution in the studied area. Very high arsenic concentrations were observed along the rivers and in the floodplain between Mekong and Bassac River (maximum $1340 \mu \mathrm{g} \mathrm{L}^{-1}$, average $233 \mu \mathrm{g} \mathrm{L}^{-1}$, median $100 \mu \mathrm{g} \mathrm{L}^{-1}$ ). The classification of three groups of well samples ("west", "middle" and "east", see section Study Area and Temporal Fluctuations) and comparison of their groundwater characteristics (Table SI 1) provides insight into the conditions promoting As release in Cambodia (see below). The concentration ranges of all species measured in this study are summarized in Table 1 for the three regions. Out of the 131 wells sampled, 63 (48\%) had concentrations above the WHO guideline value of $10 \mu \mathrm{g} \mathrm{L}^{-1}$ with 60 wells located between the two rivers. Moreover, 48 wells $(36 \%)$ exceeded the $50 \mu \mathrm{g} \mathrm{L}{ }^{-1}$ level which is the drinking water limit in many developing countries. 


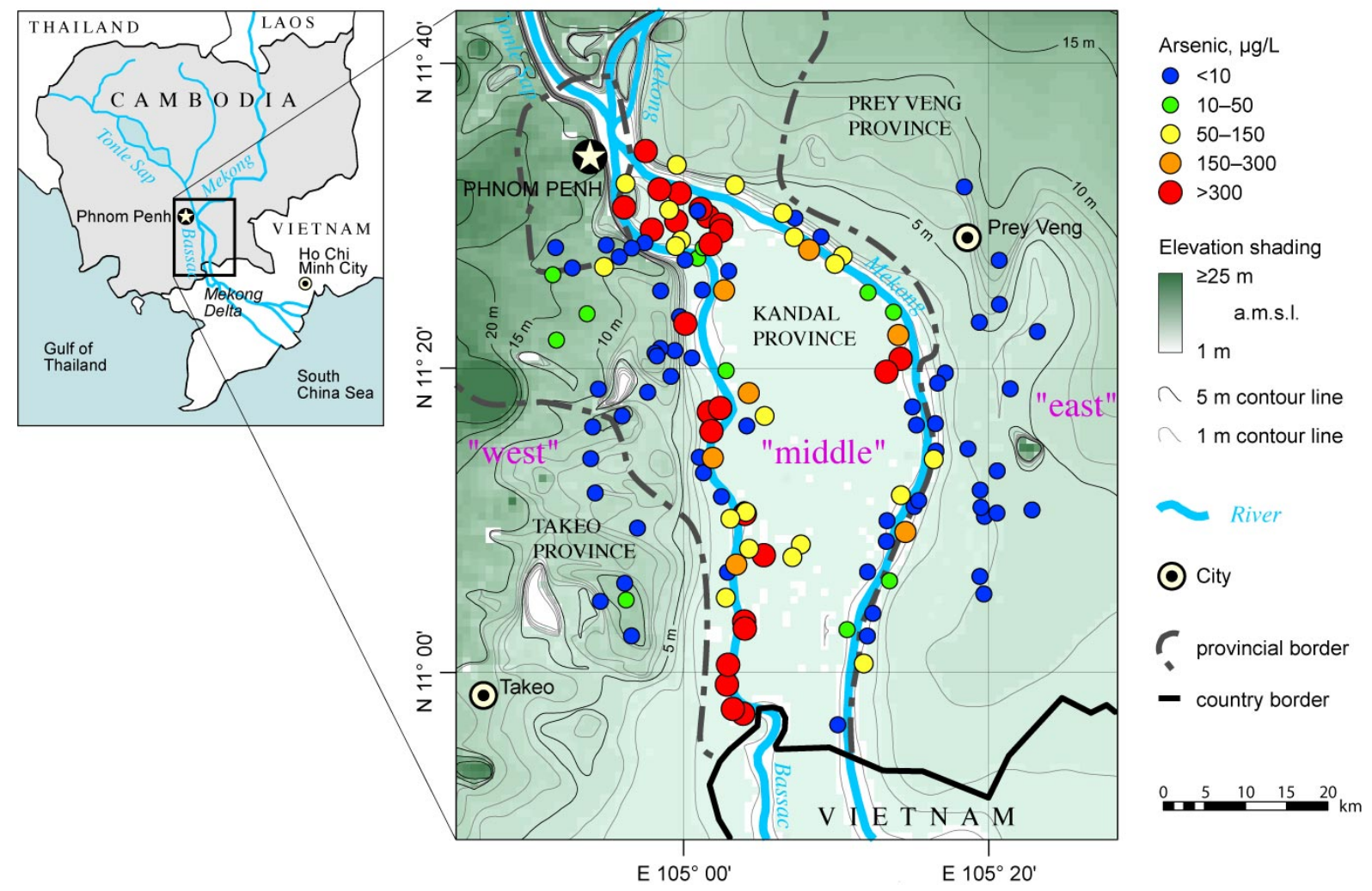

Figure 1. Arsenic concentrations measured in Cambodian groundwater collected in

November/December 2004 and March 2006. The topography on a low relief is visualized by green shading as well as $1 \mathrm{~m}$ and $5 \mathrm{~m}$ contour lines. Note 1: The highest elevation on this map is only $25 \mathrm{~m}$ a.s.1. and the terrain is rather flat with very gentle slopes of $0.2-2 \mathrm{~m} \mathrm{~km}^{-1}$. This very small slope is not recognized by eye. Note 2: Only few samples could be collected in the inner floodplain between the Mekong and Bassac Rivers because this area is swampy, scarcely populated and almost inaccessible. 
Table 1. Average concentrations (arithmetic mean), medians and ranges of groundwater parameters analyzed in the "west region", the "middle region" and the "east region". For region definition, see section Study Area and Seasons, ${ }^{a}$ determined by AFS.

\begin{tabular}{|c|c|c|c|c|c|c|c|c|c|c|}
\hline \multirow[b]{2}{*}{ Parameter } & \multirow[b]{2}{*}{ unit } & \multicolumn{3}{|c|}{ West region } & \multicolumn{3}{|c|}{ Middle region } & \multicolumn{3}{|c|}{ East region } \\
\hline & & average & median & range & average & median & range & average & median & range \\
\hline$\overline{\mathrm{As}_{\text {total }}{ }^{\mathrm{a}}}$ & $\mu \mathrm{g} \mathrm{L}^{-1}$ & 9 & 3 & $<1-100$ & 233 & 100 & $1-1340$ & 3 & 3 & $1-5$ \\
\hline $\mathrm{Fe}$ & $\mathrm{mg} \mathrm{L}^{-1}$ & 1.0 & $<0.05$ & $<0.05-10$ & 2.8 & 1.6 & $<0.05-16$ & 0.1 & $<0.05$ & $<0.05-1.3$ \\
\hline $\mathrm{Mn}$ & $\mathrm{mg} \mathrm{L}^{-1}$ & 1.1 & 1.0 & $<0.1-2.6$ & 0.6 & 0.4 & $<0.1-3.1$ & 0.3 & 0.2 & $0.1-0.9$ \\
\hline $\mathrm{Na}$ & $\mathrm{mg} \mathrm{L}^{-1}$ & 130 & 93 & $11-700$ & 79 & 44 & $9-560$ & 40 & 36 & $6-92$ \\
\hline K & $\mathrm{mg} \mathrm{L}^{-1}$ & 2.8 & 2.2 & $0.7-7.9$ & 2.9 & 2.2 & $0.4-24$ & 2.5 & 2.4 & $0.8-4.9$ \\
\hline $\mathrm{Ca}$ & $\mathrm{mg} \mathrm{L}^{-1}$ & 52 & 35 & $1-210$ & 44 & 40 & $7-220$ & 18 & 12 & $2-77$ \\
\hline $\mathrm{Mg}$ & $\mathrm{mg} \mathrm{L}^{-1}$ & 36 & 22 & $0.6-150$ & 21 & 18 & $5.2-130$ & 14 & 6.8 & $1.8-82$ \\
\hline $\mathrm{Ba}$ & $\mu \mathrm{g} \mathrm{L}^{-1}$ & 160 & 100 & $20-690$ & 414 & 260 & $20-4200$ & 103 & 77 & $12-350$ \\
\hline $\mathrm{PO}_{4}{ }^{3}-\mathrm{P}$ & $\mathrm{mg} \mathrm{L}^{-1}$ & 0.2 & $<0.2$ & $<0.2-1.4$ & 0.66 & 0.40 & $<0.2-3.14$ & $<0.2$ & $<0.2$ & $<0.2-0.44$ \\
\hline $\mathrm{H}_{4} \mathrm{SiO}_{4}-\mathrm{Si}$ & $\mathrm{mg} \mathrm{L}^{-1}$ & 24.1 & 24.7 & $15.9-31.2$ & 17.2 & 17.0 & $5.0-35.3$ & 28.6 & 30.6 & $17.3-35.5$ \\
\hline $\mathrm{HCO}_{3}^{-}$ & $\mathrm{mg} \mathrm{L}^{-1}$ & 351 & 343 & $47-838$ & 364 & 343 & $121-652$ & 166 & 124 & $34-483$ \\
\hline $\mathrm{Cl}^{-}$ & $\mathrm{mg} \mathrm{L}^{-1}$ & 152 & 39.3 & $3.5-1180$ & 63.4 & 13.5 & $1.9-709$ & 25.7 & 15.9 & $0.6-110$ \\
\hline $\mathrm{SO}_{4}{ }^{2-}$ & $\mathrm{mg} \mathrm{L}^{-1}$ & 82 & 26 & $<5-590$ & 21 & $<5$ & $<5-1000$ & 24 & 5 & $<5-310$ \\
\hline $\mathrm{NO}_{3}{ }^{-}-\mathrm{N}$ & $\mathrm{mg} \mathrm{L}^{-1}$ & 1.5 & $<0.25$ & $<0.25-22.0$ & 0.1 & $<0.25$ & $<0.25-1.9$ & $<0.25$ & $<0.25$ & $\begin{array}{r}<0.25 \\
<0.25\end{array}$ \\
\hline $\mathrm{NH}_{4}^{+}-\mathrm{N}$ & $\mathrm{mg} \mathrm{L}^{-1}$ & 0.8 & 0.2 & $<0.01-5.4$ & 6.8 & 2.7 & $<0.01-52$ & 0.2 & 0.2 & $<0.01-0.5$ \\
\hline DOC & $\mathrm{mg} \mathrm{L}^{-1}$ & 1.9 & 2.5 & $<1.5-8.1$ & 3.4 & 2.7 & $<1.5-15$ & 1.7 & 2.3 & $<1.5-3.1$ \\
\hline 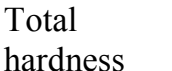 & & & & & & & & & & \\
\hline $\mathrm{pH}(\mathrm{f}$ & $\mathrm{n}$ & 6.83 & $\begin{array}{r}2.0 \\
6.77\end{array}$ & $\begin{array}{r}0.3-14 \\
5.74-7.62\end{array}$ & $\begin{array}{r}2.1 \\
7.03\end{array}$ & $\begin{array}{r}2.0 \\
7.02\end{array}$ & $\begin{array}{r}0.4-11 \\
6.55-7.65\end{array}$ & $\begin{array}{r}1.1 \\
6.41\end{array}$ & $\begin{array}{r}0.0 \\
6.57\end{array}$ & $\begin{array}{r}0.2-5.5 \\
5.42-6.85\end{array}$ \\
\hline $\mathrm{E}_{\mathrm{c}}$ (field) & $\mu \mathrm{S} \mathrm{cm}^{-1}$ & 1300 & 744 & $92-6150$ & 870 & 741 & 243-3597 & 420 & 300 & $78-1220$ \\
\hline $\mathrm{E}_{\mathrm{h}}$ (field) & $\mathrm{mV}$ & 0 & 0 & $-128-96$ & -78 & -80 & $-408-45$ & 14 & 20 & $-62-72$ \\
\hline $\mathrm{T}$ (field) & ${ }^{\circ} \mathrm{C}$ & 30.0 & 30.1 & $29.1-30.8$ & 29.4 & 29.4 & $28.2-30.2$ & 29.9 & 29.9 & $29.3-30.6$ \\
\hline well depth & $\mathrm{m}$ & 26 & 25 & $9-40$ & 40 & 40 & $17-65$ & 33 & 33 & $22-48$ \\
\hline $\mathrm{Co}$ & $\mu \mathrm{g} \mathrm{L}^{-1}$ & 1.4 & 0.9 & $0.1-5.7$ & 0.3 & 0.0 & $0.1-2.6$ & 2.3 & 0.6 & $0.1-17$ \\
\hline $\mathrm{Ni}$ & $\mu \mathrm{g} \mathrm{L}^{-1}$ & 3.3 & 2.3 & $1.0-23$ & 2.5 & 1.9 & $0.4-11$ & 4.8 & 3.6 & $1.1-23$ \\
\hline $\mathrm{Cu}$ & $\mu \mathrm{g} \mathrm{L}^{-1}$ & 7.8 & 6.1 & $2.6-31$ & 6.2 & 6.2 & $0.4-21$ & 8.5 & 7.8 & $4.8-18$ \\
\hline $\mathrm{Cr}$ & $\mu \mathrm{g} \mathrm{L}^{-1}$ & 2.1 & 0.4 & $<0.1-14$ & 0.4 & 0.3 & $<0.1-2$ & 0.3 & 0.3 & $<0.2-0.6$ \\
\hline $\mathrm{U}$ & $\mu \mathrm{g} \mathrm{L}^{-1}$ & 5.8 & 3.1 & $<0.1-32$ & 1.1 & 0.1 & $<0.1-9.3$ & 1.1 & 0.1 & $<0.1-8.1$ \\
\hline $\mathrm{Cd}$ & $\mu \mathrm{g} \mathrm{L}^{-1}$ & 0.2 & 0.1 & $0.1-1.0$ & 0.1 & 0.1 & $0.1-2.3$ & 0.2 & 0.1 & $0.1-0.6$ \\
\hline
\end{tabular}

The average arsenic concentration in the "middle region" is significantly higher than in the "west" and "east region" (see Table SI 2 for statistical verification). Furthermore, groundwater in the "middle region" has significantly lower average $\mathrm{E}_{\mathrm{h}}$, higher DOC, $\mathrm{NH}_{4}{ }^{+}$, $\mathrm{HCO}_{3}{ }^{-}, \mathrm{PO}_{4}{ }^{3-}$ and $\mathrm{Fe}(\mathrm{II})$ concentrations (Figure 2a, Table SI 2). Thus, this groundwater is reducing in nature, supported by the fact that almost all inorganic $\mathrm{N}$ is present in the reduced $\mathrm{NH}_{4}{ }^{+}$species (only 7 of 90 samples had traces of $\mathrm{NO}_{3}{ }^{-}$ranging from 0.2 to $1.9 \mathrm{mg} \mathrm{L}^{-1}$ ). A few wells in the "middle region" have low As concentrations despite $\mathrm{E}_{\mathrm{h}}$ values that are below $150 \mathrm{mV}$. This might be due to $\mathrm{As}_{2} \mathrm{~S}_{3}$ precipitation under sulphate reducing conditions (16). Concentrations of $\mathrm{NH}_{4}{ }^{+}$and DOC show a weak, but positive correlation with As $\left(\mathrm{r}^{2}=0.46\right.$ and 0.44, respectively, Figures SI 5a, b). Considering these facts, As release seems to be 
triggered by microbially induced reductive dissolution of As-coated iron oxides and $\mathrm{MnO}_{2}$ surfaces. Principal Component Analysis supports this hypothesis (see Statistical Analysis in Methods Section).
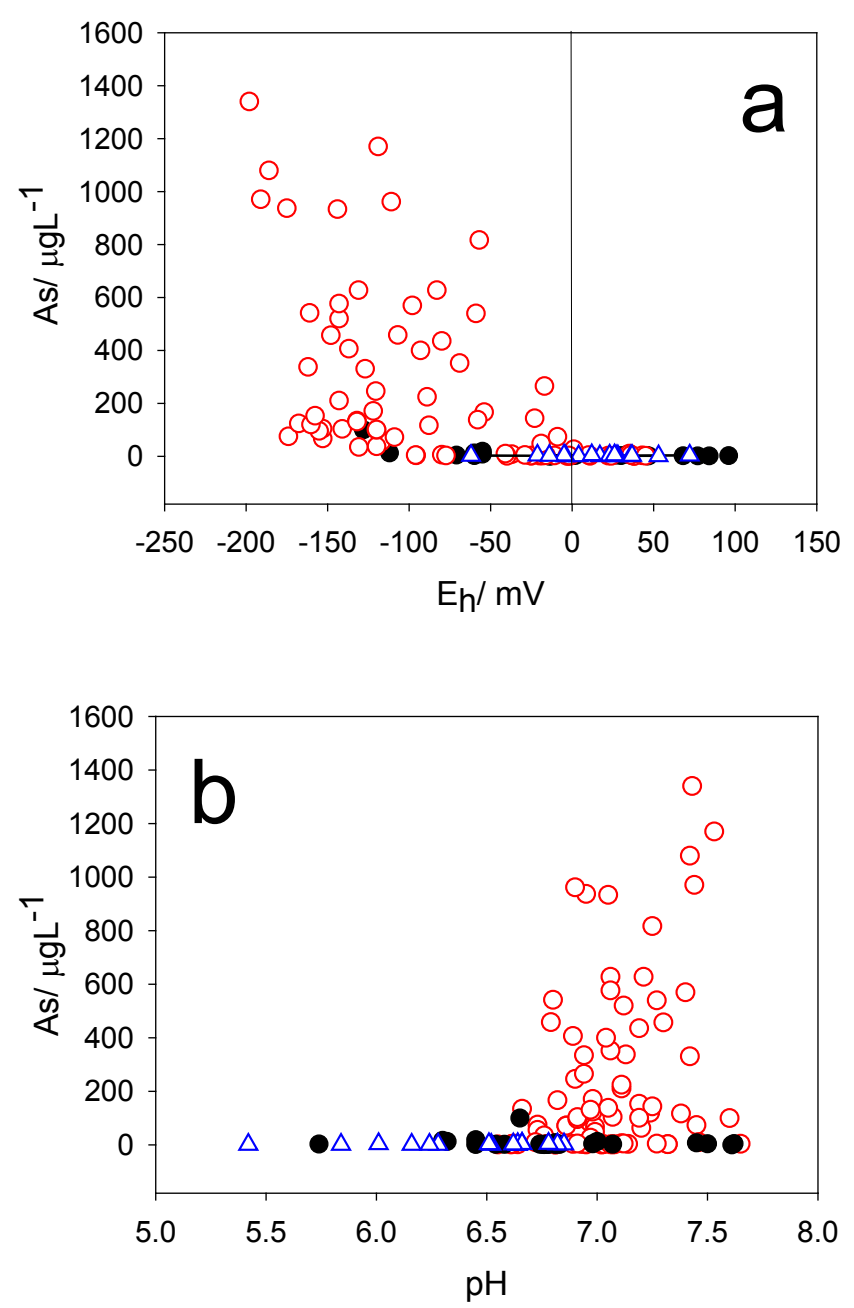

Figure 2 a, b. Arsenic concentration as a function of (a) redox potential, $\mathrm{E}_{\mathrm{h}}$, and (b) $\mathrm{pH}$ in the "west region" $(\bullet)$, "middle region" $(\circ)$ and "east region" $(\Delta)$.

As can be seen in Figure $2 b$, very high As concentrations $\left(>1000 \mu \mathrm{g} \mathrm{L^{-1 }}\right)$ were accompanied by $\mathrm{pH}$ values $>7.3$. Neutral to high $\mathrm{pH}$ conditions favour As release by promoting desorption processes compared to the predominantly acidic conditions found in the "west" and "east region" $(1,3,17)$. High arsenic concentrations in the studied area of Cambodia are clearly triggered by reducing conditions, and $\mathrm{pH} \geq 7$ might possibly enhance the mobilization of As at some locations.

Sediment coring and analysis was beyond the scope of this study and omitted because the composition of sediments is not necessarily indicative of the aqueous phase composition 
$(18,19)$. Or in the words by Meharg et al.: “...the solid-to-solution mass transfers of As required to produce contaminated groundwater are small in relation to the total amount of As in the sediments. This makes it difficult to use mineral mass balances to deduce the mobilization and precipitation mechanisms responsible for the high-As groundwaters" (20).

Manganese contamination. The "west region" exhibits suboxic conditions $\left(\mathrm{E}_{\mathrm{h}} \approx 0\right)$ with low As concentrations $\left(9 \mu \mathrm{g} \mathrm{L}^{-1}\right)$, but it contains significantly higher average Mn levels $(1.1 \mathrm{mg} \mathrm{L}$ $\left.{ }^{1}\right)$ compared to the "middle region" $\left(0.6 \mathrm{mg} \mathrm{L}^{-1}\right)$ and the "east region" $\left(0.3 \mathrm{mg} \mathrm{L}^{-1}\right)$ (Table SI 2). This finding indicates that $\mathrm{MnO}_{2}$ is reduced and $\mathrm{Mn}^{2+}$ released to the aqueous phase. The $E_{h}$ values seem to be generally not low enough to entirely reduce sediment-bound iron(hydr)oxides (low dissolved iron levels) which therefore still offer strong binding sites for As and phosphate. The absence of nitrate in 20 of 24 wells supports the hypothesis of $\mathrm{MnO}_{2}$ reducing conditions. On the other hand, a weak but positive correlation is found for $\mathrm{Mn}$ concentrations with $\mathrm{E}_{\mathrm{h}}$ (Figure 3a). This might be due to $\mathrm{MnCO}_{3}$ precipitation (the "west region" is slightly over-saturated with respect to $\mathrm{MnCO}_{3} ; Q_{s p}=3.210^{-11}>K_{s p}=1.810^{-11}$ ) and/or - to a lesser extent - MnS precipitation at lower $E_{h}$ values (Table SI 4). As a result of such redox conditions, elevated Mn levels are strongly anti-correlated with As (the higher the As level, the lower the Mn level and vice versa) (Figure 3b).

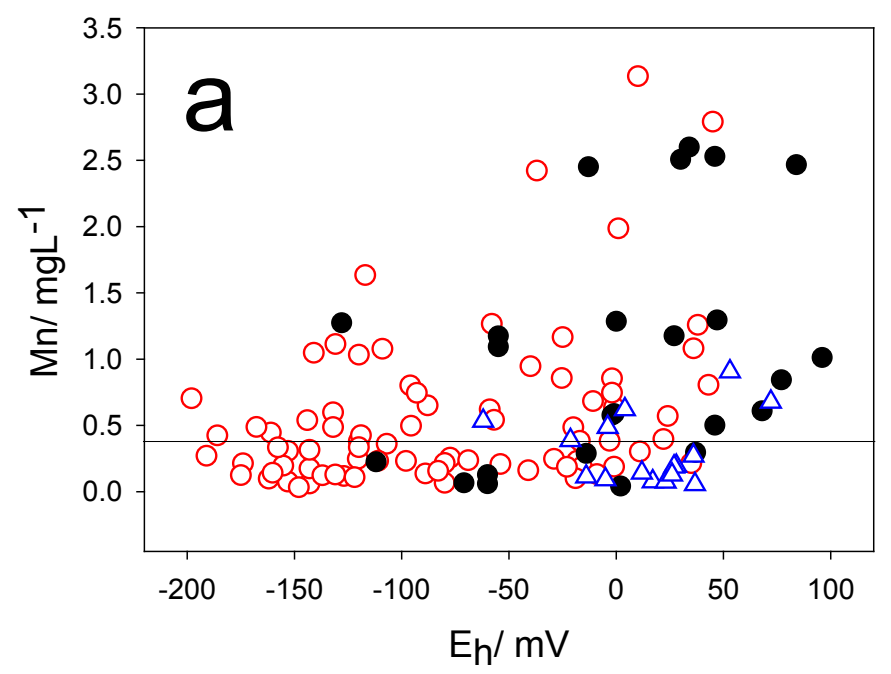




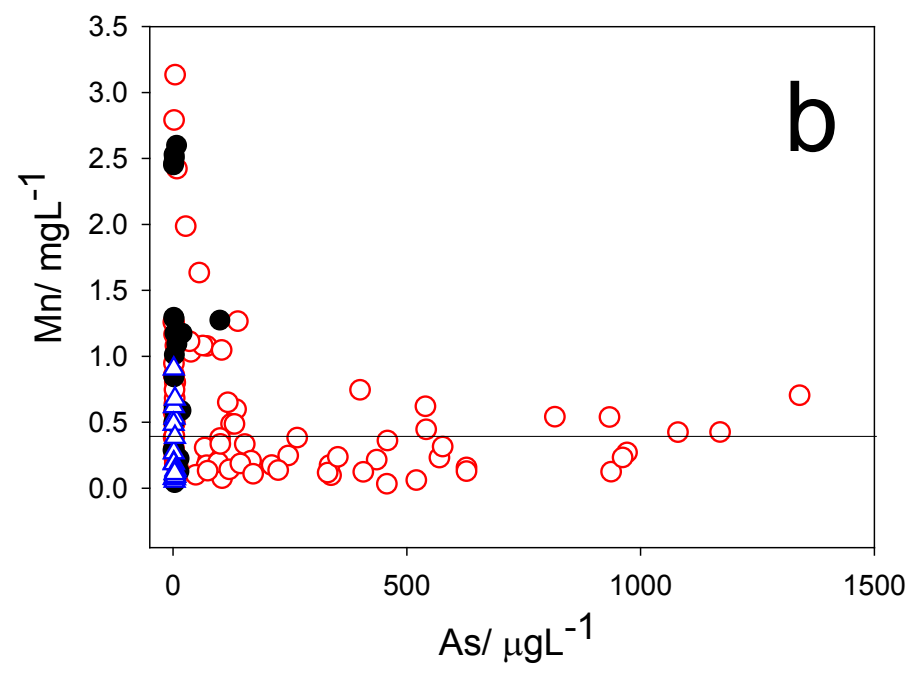

Figure 3 a,b. Manganese concentration as a function of (a) $E_{h}$ and (b) As concentration, in the "west region" $(\bullet)$, "middle region" $(\circ)$ and "east region" $(\Delta)$. The line at $0.4 \mathrm{mg} \mathrm{L}^{-1}$ represents the WHO guideline (21).

Elevated Mn concentrations have an impact on plants and human beings. Manganese is one of the major factors limiting crop production on acidic soil (about 30\% of the world's total land area) (22). In plants, symptoms such as chlorosis (photooxidation of chlorophyll) and necrosis due to accumulation of phenolic compounds are observed. It has also been shown that maternal environmental exposure to $\mathrm{Mn}$ is associated with a reduced activity of the newborn's erythrocyte Ca-pump (23). Furthermore, exposure to Mn in drinking water is associated with neurotoxic effects in children, for example with a diminished intellectual function (24). Consequently, high Mn concentrations in irrigation and drinking water are hazardous for plants and human beings. It is worth noting that out of 131 wells sampled, 75 (57\%) exhibit Mn concentrations $>0.4 \mathrm{mg} \mathrm{L}^{-1}$ (Figure 3a, b). Upon oxidation, Mn leads to clouding of drinking water by precipitation of $\mathrm{MnO}_{2}$ which is, however, a rather slow process. Although in the west of Bassac River groundwater use for drinking water purposes might be regarded as chemically safe with respect to arsenic, average manganese concentrations are notably above the WHO guideline value.

Coincidence of Low relief Topography with Areas of Elevated Arsenic Levels. The low relief topography depicted in Figure 1 features a flat area confined between the rivers (max. 1 $m$ altitude variation) that is accompanied by tiny gradual slopes of only $0.2-2 \mathrm{~m} \mathrm{~km}^{-1}$ to the 
west and to the east. These slopes cannot be recognized by eye and thus seem totally flat to the observer, however, they become apparent in the shaded contour plot that we derived from the USGS digital elevation model GTOPO30 by interpolation with ArcGIS (Figure 1).

Obviously, elevated groundwater As levels are exclusively present in the flat land embraced by Mekong and Bassac as well as on the adjacent river banks. To the best of our knowledge, such sharply confined risk areas have not been reported elsewhere.

We suggest that the present low relief of the studied area is indicative for the distribution of arsenic in groundwater in the studied area. Although our present knowledge is too limited to provide clear evidence for a causal link between topography and arsenic risk areas, there is a number of basic indications. The shallow valley was deeper after the Pleistocene period and was then filled with Holocene alluvial deposits. Satellite pictures reveal that former river channels (seen as oxbows and old meanders) are almost exclusively situated between the two rivers, but not to the east and west (Figure SI 6). It can further be noted that during the dry season only the "middle region" retains enough water to sustain vegetation and wetlands while the "slopes" in the east and the west lay barren (Figure SI 7). Wetlands as the ones formed between the rivers are known to accumulate natural organic matter in the buried sediments (25).

Consequently, the present-day topography appears to reflect the boundary of organic-rich Holocene sediments deposited between the rivers. This is supported by findings of M. L. Polizzotto et al. (personal communication) stating "The Holocene stratigraphy between the rivers is featuring $10-20 \mathrm{~m}$ of clay overlaying fine grey sand which persists down to $\approx 45-60$ $\mathrm{m}$. The clay layer becomes anoxic below the groundwater table, with abundant organic matter, often in the form of large pieces of wood. Many variations from this general characterization are present".

Major cations and anions. Total water hardness is 2-3 times higher in the "west region" compared to the "middle" and "east region" (Table 1 ). The $\mathrm{Na} / \mathrm{Cl}$ ratios being $>1$ in most of these samples suggests ion exchange by $\mathrm{Ca}$ on clays (Figures SI $8 \mathrm{a}, \mathrm{b}$ ). The stoichiometric ratios of Ca:Mg = 1:1.1 (ideally $1: 1$ for $\mathrm{CaMg}\left(\mathrm{CO}_{3}\right)_{2}$ ) and $\mathrm{Ca}: \mathrm{HCO}_{3}=0.3: 1$ (ideally 0.25:1) found in the water samples imply dissolution of $\mathrm{CaMg}\left(\mathrm{CO}_{3}\right)_{2}$ (Figures $\mathrm{SI} 8 \mathrm{c}, \mathrm{d}$ ). Thus, the origin of the alkalinity is predominantly based on the dissolution of dolomite.

The pronounced gradient of total hardness from the "west" to the "middle" and "east" indicates that groundwater in the "west" and the "east" is influenced by other sources than river water infiltration. Obviously, the sharply confined arsenic risk areas exhibit different 
total hardness. Again, the low relief topography coincides with the groundwater composition as discussed above.

According to the relative molar portion of the dissolved ionic species, groundwater in the "middle region" is of $\mathrm{Ca}-\mathrm{Mg}-(\mathrm{Na})-\mathrm{HCO}_{3}$ type (40\%), the rest dominated by $\mathrm{Mg}-\mathrm{Ca}-\mathrm{Na}-$ $\mathrm{HCO}_{3}$ and $\mathrm{Na}-\mathrm{Ca}-\mathrm{Mg}-\mathrm{HCO}_{3}$ (Figure 4). The "west" and "east" regions are mainly of the Na$(\mathrm{Mg})-\mathrm{HCO}_{3}-(\mathrm{Cl})$ type. There is a mixing trend towards more sodium rich water with distance from the rivers Mekong and Bassac. The few "middle region" samples that show a clear Ca$\mathrm{Mg}$ prevalence are situated very close to the rivers, and might therefore be predominantly infiltrated river water. This is supported by the fact that Mekong River water composition shows also a clear Ca-Mg prevalence (Figure 4) (11).

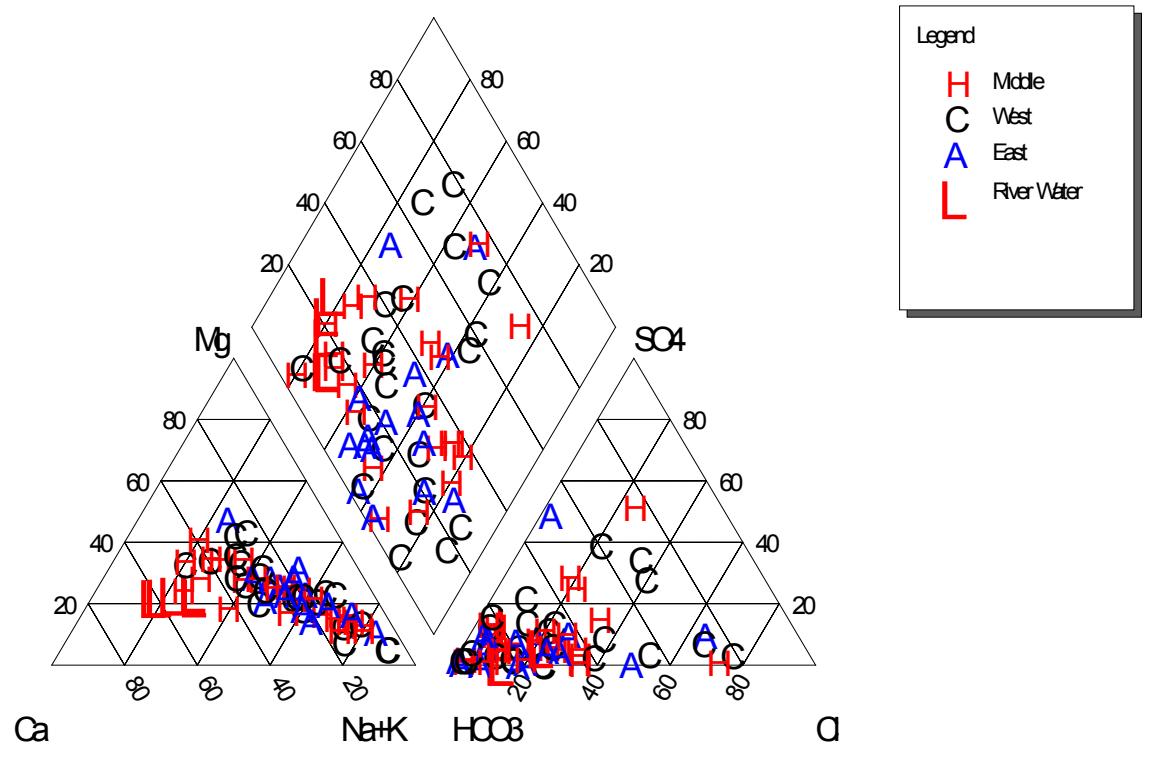

Figure 4. Piper diagram depicting the main hydrochemical conditions of the three groups of groundwater in this study, river water (Bassac, Tonle Sap River, Mekong north of and south of Phnom Penh (Table SI 1)) and of Mekong River water (11).

Well depths. Although our study revealed As levels between 1-460 $\mu \mathrm{g} \mathrm{L} \mathrm{L}^{-1}$ in shallow wells (15-20 m), concentrations were generally higher (up to $>1000 \mu \mathrm{g} \mathrm{L}^{-1}$ ) between $25-45 \mathrm{~m}$ depth (Figure SI 9). The deepest well of our study was $65 \mathrm{~m}$. The wells in the "west" and "east region" are on average not as deep as the ones in the "middle region". There is, however, 
no correlation between region, well depth and As concentration. In other words, although the "east" and "west region" have numerous wells with depths of 25-40 m, they all have very low As levels.

Fluctuations in groundwater composition. To elucidate temporal fluctuations of groundwater constituents, 26 tube-wells were sampled in a special study area of Kandal Province three times over a time span of 9 month, i.e., in April 04, August 04 and January 05 (for locations, see Figure SI 1). Average As, $\mathrm{Mn}, \mathrm{Fe}, \mathrm{PO}_{4}{ }^{3-}, \mathrm{SO}_{4}{ }^{2-}, \mathrm{NH}_{4}{ }^{+}$and DOC concentrations for each season were not significantly different from each other taking only time as a factor in the statistical analysis of variance. However, ANOVAs considering each individual well as a second (random) factor showed that concentrations differed significantly with time (Table SI 3). Yet, compared to the differences found between the three regions, these fluctuations were small. The deviations from average $(n=3$, maximum $25 \%)$ are shown for As in Figure SI 10. Although DOC, $\mathrm{NH}_{4}{ }^{+}, \mathrm{PO}_{4}{ }^{3-}$ and $\mathrm{Fe}$ had higher average values in April compared to August or January (Figures SI 3 a, b), these parameters were not accompanied by a lower $\mathrm{E}_{\mathrm{h}}$ value. Due to altered directions of the groundwater flow caused by changing groundwater heads, the tube-wells possibly received water from shifted flow paths over the seasons. Nevertheless, it can be concluded that fluctuations of groundwater composition over time are small compared to regional differences. In contrast to the assertion by Stanger et al., the arsenic levels in groundwater are by no means ephemeral (7). Concentrations of major cations and anions remained constant over the 9-month study period and so did concentrations of heavy metals, leading to a constant total hardness of these groundwater samples. No significant dilution was observed during the inundation period.

Health Considerations. Figure 5 shows the cumulative frequencies for As and $\mathrm{Mn}$ concentration ranges in the three regions studied. The high arsenic concentrations in the Kandal Province are posing an alarming health threat to the people that consume this water daily. In addition, the elevated Mn levels found in Prey Vêng Province must be considered harmful for infant children. Out of 131 wells, $48 \%$ had As concentrations exceeding the WHO guideline value $\left(10 \mu \mathrm{g} \mathrm{L}^{-1}\right)$ and $57 \%$ had Mn concentrations higher than $0.4 \mathrm{mg} \mathrm{L}^{-1}$ (WHO). While high Mn concentrations were often coupled with low As concentrations and vice versa (Figure 3b), many wells exhibited an As problem, others had a Mn problem and only $18 \%$ provided chemically safe drinking water. The long-term health impact for the 1.2 
million people drinking this groundwater without treatment is profound if remedial actions are not taken. Simple and low-cost mitigation measures for the household level include sand filters for arsenic removal, ion exchange, activated alumina, modified coagulation/ filtration and lime softening. Sand filters were demonstrated to operate effectively if groundwater contains $>1 \mathrm{mg} \mathrm{L}^{-1}$ iron and $<2 \mathrm{mg} \mathrm{L}^{-1}$ phosphate (26). In the highly affected "middle" region, $52 \%$ of the wells had $\mathrm{Fe}>1 \mathrm{mg} \mathrm{L}^{-1}$ and $26 \%$ had $\mathrm{Fe}>5 \mathrm{mg} \mathrm{L}^{-1}$ (with $\mathrm{As}>10 \mu \mathrm{g} \mathrm{L}^{-1}$ and phosphate $\left.<2 \mathrm{mg} \mathrm{L}^{-1}\right)$. Compared to Vietnam $\left(86 \%\right.$ with $\left.\mathrm{Fe}>1 \mathrm{mg} \mathrm{L}^{-1}, \mathrm{n}=134\right)$ and Bangladesh ( $69 \%$ with $\left.\mathrm{Fe}>1 \mathrm{mg} \mathrm{L}^{-1}, \mathrm{n}=3284\right)$, on average less dissolved iron is present in Cambodia restricting the potential use of arsenic removal by sand filters to a lower percentage (26).
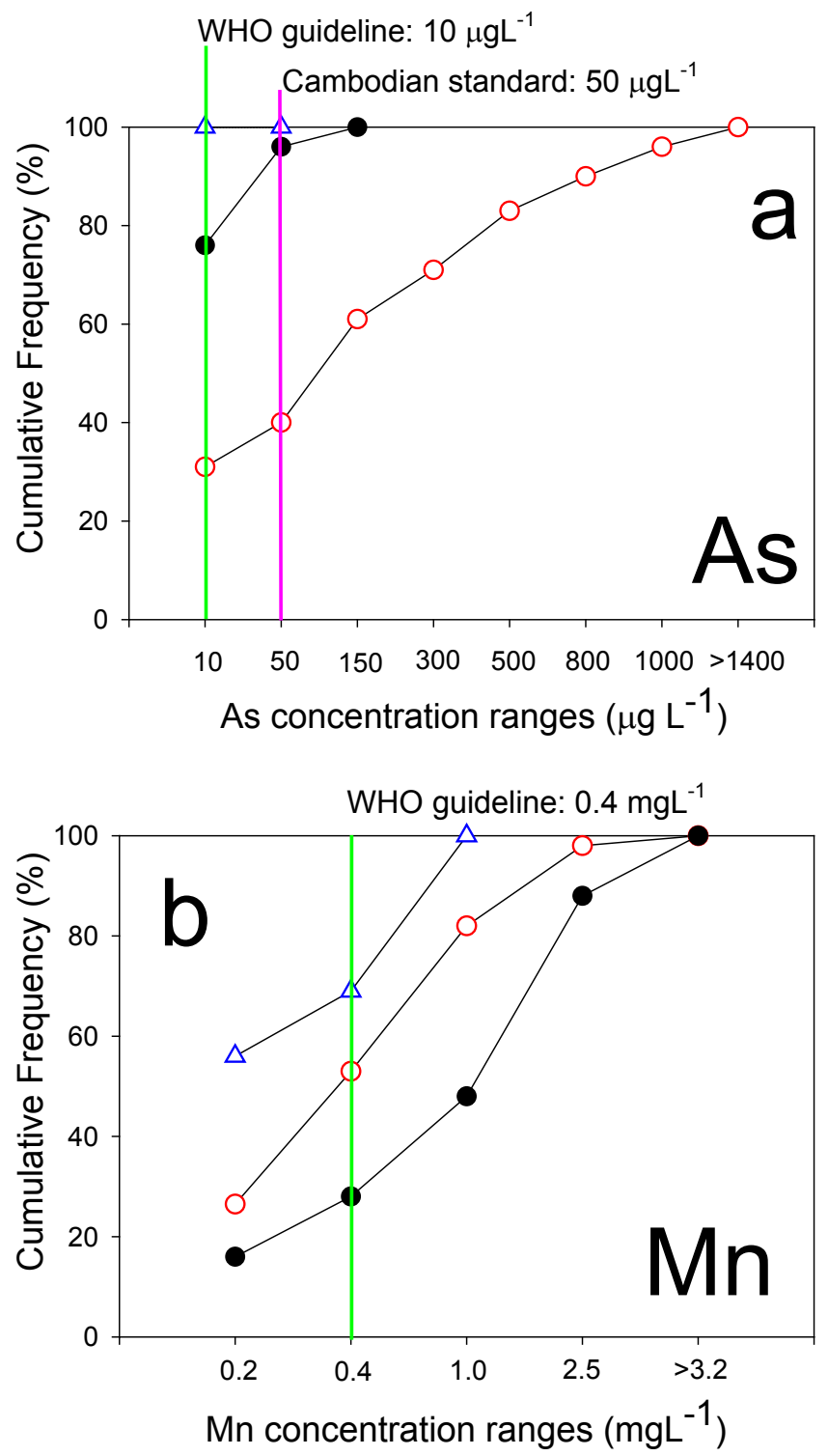
Figure 5. Cumulative frequency distributions of (a) arsenic and (b) manganese concentration ranges of groundwaters in the "west region" $(\bullet)$, "middle region" $(\circ)$ and "east region" $(\Delta)$, where $0.2 \mathrm{mg} \mathrm{L}^{-1} \mathrm{Mn}$ means the range $0-0.2 \mathrm{mg} \mathrm{L}^{-1}$.

Most of the tube-wells were built during the last ten years. Incidents of chronic As related diseases such as arsenicosis were already reported (M. Sampson, personal communication). Because arsenicosis is known to occur after 10-15 years of chronic As ingestion $\left(>50 \mu \mathrm{g} \mathrm{L}^{-1}\right)$, people drinking contaminated water are exposed to a serious health risk. Skin lesions in children and significantly higher As levels in human hair samples of people living in Kandal Province are proof that the problem must be taken seriously (27). In addition, the elevated Mn concentrations should be considered. Infant mortality in Cambodia is $71 / 1000$ which is 18 times higher than in central Europe (4). The health impact of Mn is known to be harmful for newborns and children $(23,24)$.

With 350 people $\mathrm{km}^{-2}$ potentially exposed to chronic arsenic poisoning, the magnitude is similar to Bangladesh (200 km $\left.\mathrm{km}^{-2}(1)\right)$, West Bengal $\left(250 \mathrm{~km}^{-2}(1)\right)$ or Vietnam $\left(270 \mathrm{~km}^{-2}\right.$ (2). This health threat justifies international recognition. Consequently, we urgently propose early mitigation actions in order to reduce the risk of chronic arsenic poisoning of a million people living in Kandal Province.

Besides a scientifically sound distinction of relevant geochemical factors, we have shown that the present topography (low relief) coincides with sharply confined high and low arsenic areas, and that it reflects the boundary of recent Holocene sediment deposits. We believe such topography is a worthy indicator to be considered in As groundwater studies.

\section{Acknowledgements}

We thank the Wolfermann-Nägeli foundation (Switzerland) for financial support. Moniphea Leng, Mengieng Ung, Samreth Sopheap, Kagna Ouch, Um Rachana and Vong Sovathana are acknowledged for their support in field work. We are indebted to Rosi Siber for elevation modeling of Figure 1, as well as Jakov Bolotin, David Kistler, Madeleine Langmeier and the AuA team for technical support. Laura Sigg, Stephan Klump and four anonymous reviewers are acknowledged for reviewing the manuscript. 


\section{Supporting Information Available}

Full geo-referenced database of 30 parameters measured in the groundwater samples, details and results of quality assurance, statistical analyses of variance (ANOVA), principal component analysis (PCA), several plots of cross-correlation, temporal variations of arsenic, and satellite pictures of the study area. This material is available free of charge via the Internet at http://pubs.acs.org. 


\section{Literature Cited}

(1) Smedley, P. L.; Kinniburgh, D. G. A review of the source, behaviour and distribution of arsenic in natural waters. Appl. Geochem. 2002, 17, 517-568.

(2) Berg, M.; Tran, H. C.; Nguyen, T. C.; Pham, H. V.; Schertenleib, R.; Giger, W. Arsenic contamination of groundwater and drinking water in Vietnam: a human health threat. Environ. Sci. Technol. 2001, 35, 2621-2626.

(3) Welch, A. H.; Lico, M. S.; Hughes, J. L. Arsenic in groundwater of the Western United-States. Ground Water 1988, 26, 333-347.

(4) http://worldfacts.us/Cambodia.htm.

(5) Feldman, P. R.; Rosenboom, J. W. Cambodia Drinking Water Quality Assessment., World Health Organisation of the UN (WHO) in cooperation with Cambodian Ministry of Rural Development and the Ministery of Industry, Mines and Energy, Editors, Phnom Penh, 2001.

(6) Polya, D. A.; Gault, A. G.; Diebe, N.; Feldman, P.; Rosenboom, J. W.; Gilligan, E.; Fredericks, D.; Milton, A. H.; Sampson, M.; Rowland, H. A. L.; Lythoge, P. R.; Jones, J. C.; Middleton, C.; Cooke, D. A. Arsenic hazard in shallow Cambodian groundwaters. Mineral. Mag. 2005, 69, 807-823.

(7) Stanger, G.; VanTruong, T.; Ngoc, K.; Luyen, T. V.; Thanh, T. T. Arsenic in groundwaters of the Lower Mekong. Environ. Geochem. Health 2005, 27, 341-357.

(8) Polya, D. A.; Gault, A. G.; Bourne, N. J.; Lythgoe, P. R.; Cooke, D. A. Coupled HPLC-ICP-MS analysis indicates highly hazardous concentrations of dissolved arsenic species are present in Cambodian wellwaters. Royal Society of Chemistry Special Publication 2003, 288, 127-140.

(9) Trang, P. T. K.; Berg, M.; Viet, P. H.; Van Mui, N.; Van Der Meer, J. R. Bacterial bioassay for rapid and accurate analysis of arsenic in highly variable groundwater samples. Environ. Sci. Technol. 2005, 39, 7625-7630.

(10) Ta, T. K. O.; Nguyen, V.; Tateishi, M.; Kobayashi, I.; Saito, Y. Sedimentary facies, diatom and foraminifer assemblages in a late Pleistocene-Holocene incised-valley sequence from the Mekong River Delta, Bentre Province, Southern Vietnam: the BT2 core. J. Asian Earth Sci. 2001, 20, 83-94.

(11) Meybeck, M.; Carbonnel, J. P. Chemical transport by Mekong River. Nature 1975, 255, 134-136.

(12) Nguyen, V. L.; Ta, T. K. O.; Tateishi, M. Late Holocene depositional environments and coastal evolution of the Mekong River Delta, Southern Vietnam. J. Asian Earth Sci. 2000, 18, 427-439.

(13) Ta, T. K. O.; Nguyen, V. L.; Tateishi, M.; Kobayashi, I.; Saito, Y.; Nakamura, T. Sediment facies and Late Holocene progradation of the Mekong River Delta in Bentre Province, southern Vietnam: an example of evolution from a tide-dominated to a tideand wave-dominated delta. Sediment. Geol. 2002, 152, 313-325.

(14) Pham, V. N.; Boyer, D.; Le Mouel, J. L.; Nguyen, T. K. T. Hydrogeological investigation in the Mekong Delta around Ho-Chi-Minh City (South Vietnam) by electric tomography. C. R. Geosci. 2002, 334, 733-740.

(15) Stahel, W. A. Statistische Datenanalyse; 4th ed. Braunschweig Vieweg, 2002.

(16) Helz, G. R.; Tossell, J. A.; Charnock, J. M.; Pattrick, R. A. D.; Vaughan, D. J.; Garner, C. D. Oligomerization in As(III) sulfide solutions - theoretical constraints and spectroscopic evidence. Geochim. Cosmochim. Acta 1995, 59, 4591-4604.

(17) Dixit, S.; Hering, J. G. Comparison of arsenic(V) and arsenic(III) sorption onto iron oxide minerals: Implications for arsenic mobility. Environ. Sci. Technol. 2003, 37, 4182-4189. 
(18) Harvey, C. F.; Swartz, C. H.; Badruzzaman, A. B. M.; Keon-Blute, N.; Yu, W.; Ali, M. A.; Jay, J.; Beckie, R.; Niedan, V.; Brabander, D.; Oates, P. M.; Ashfaque, K. N.; Islam, S.; Hemond, H. F.; Ahmed, M. F. Arsenic mobility and groundwater extraction in Bangladesh. Science 2002, 298, 1602-1606.

(19) Bone, S. E.; Gonneea, M. E.; Charette, M. A. Geochemical cycling of arsenic in a coastal aquifer. Environ. Sci. Technol. 2006, 40, 3273-3278.

(20) Meharg, A. A.; Scrimgeour, C.; Hossain, S. A.; Fuller, K.; Cruickshank, K.; Williams, P. N.; Kinniburgh, D. G. Codeposition of organic carbon and arsenic in Bengal Delta aquifers. Environ. Sci. Technol. 2006, 40, 4928-4935.

(21) WHO Principles and methods for the assessment of risk from essential trace elements., World Health Organization, Editors, Geneva, 2002.

(22) Alam, S.; Kodama, R.; Akiha, F.; Kamei, S.; Kawai, S. Alleviation of manganese phytotoxicity in barley with calcium. J. Plant Nutr. 2006, 29, 59-74.

(23) Yazbeck, C.; Moreau, T.; Sahuquillo, J.; Takser, L.; Huel, G. Effect of maternal manganese blood levels on erythrocyte calcium-pump activity in newborns. Sci. Total Environ. 2006, 354, 28-34.

(24) Wasserman, G. A.; Liu, X. H.; Parvez, F.; Ahsan, H.; Levy, D.; Factor-Litvak, P.; Kline, J.; van Geen, A.; Slavkovich, V.; Lolacono, N. J.; Cheng, Z. Q.; Zheng, Y.; Graziano, J. H. Water manganese exposure and children's intellectual function in Araihazar, Bangladesh. Environ. Health Perspect. 2006, 114, 124-129.

(25) McArthur, J. M.; Banerjee, D. M.; Hudson-Edwards, K. A.; Mishra, R.; Purohit, R.; Ravenscroft, P.; Cronin, A.; Howarth, R. J.; Chatterjee, A.; Talukder, T.; Lowry, D.; Houghton, S.; Chadha, D. K. Natural organic matter in sedimentary basins and its relation to arsenic in anoxic ground water: the example of West Bengal and its worldwide implications. Appl. Geochem. 2004, 19, 1255-1293.

(26) Berg, M.; Luzi, S.; Trang, P. T. K.; Viet, P. H.; Giger, W.; Stüben, D. Arsenic removal from groundwater by household sand filters - comparative field study, model calculations, and health benefits Environ. Sci. Technol. 2006, 40, 5567-5573.

(27) Berg, M.; Stengel, C.; Trang, P. T. K.; Pham, H. V.; Sampson, M.; Leng, M.; Samreth, S.; Fredericks, D. Magnitude of arsenic pollution in the Mekong and Red River Deltas - Cambodia and Vietnam. Sci. Total Environ. 2007, 372, 413-425. 


\section{Brief}

Based on a comprehensive groundwater survey conducted in Cambodia, this study reveals sharply confined risk areas of arsenic and manganese contamination that have not been recognized previously. 